NASKHI
Jurnal Kajian Pendidikan dan Bahasa Arab
Volume 3, No. 2, 2021
ISSN (print) : 2527-5747
ISSN (online) : 2716-3369
Homepage : https://journal.iaimsinjai.ac.id/index.php/naskhi

\title{
فعالية كتاب "قواعد الإملاء" لعبد السلام محمد هارون في ترقية مهارة كتابة همزة الوصل والقطع مدم هم
}

\author{
Muhammad Mulkan \\ UIN Walisongo, Semarang \\ E-mail: muhammadmulkan29@gmail.com,Tlp: +6282137000326 \\ DOI: https://doi.org/10.47435/naskhi.v3i2.689
}

This work is licensed under a Creative Commons Attribution-ShareAlike 4.0 International License.

\begin{abstract}
The backgrounds for students of Arabic Language Education who attend Qowa'id Imla' lectures are not the same, therefore it is hoped that students of Arabic Language Education can write well in Qowa'id Imla' lectures using the book by "Abdussalam Muhammad Harun". The purpose of this research was to prove the effectiveness of using Abdussalam Muhammad Harun's book in improving the writing of Hamzah Washal and Qatha'. This type of research is qualitative research, that produces descriptive, field research, and the techniques used are Observation, Documentation, Interview, and Test. The results of this research are based on the average value obtained from 3 classes, the result of Pretest is 53.53 and Posttest is 58.72. from these results indicate that the use of the book Qowa'id Imla 'by Abdusslam Muhammad Harun is less effective in improving the writing skills of Hamzah Washal and Qatha'. There are several reasons, the lack of understanding of the material in the book because the book used is in Arabic, lack of attention when the lecturer is giving class material, and lack of time in understanding all the material about hamzah washal and qatha', and lack of writing practice during hamzah material. washal and qatha'.
\end{abstract}

\section{Keywords: Abdussalam M. Harun, Hamzah and Writing}

\begin{abstract}
Abstrak
Latar belakang para mahasiswa Pendidikan Bahasa Arab yang mengikuti perkuliahan Qowa'id Imla' tidaklah sama, oleh karena itu diharapkan bagi mahasiswa Pendidikan Bahasa Arab dapat menulis dengan baik dalam perkuliahan Qowa'id Imla' dengan menggunakan kitab karya "Abdussalam Muhammad Harun”. Tujuan penelitian ini adalah untuk membuktikan keefektifitasan penggunaan kitab karya Abdussalam Muhammad Harun dalam meningkatkan menulis Hamzah Washal dan Qatha'. Jenis penelitian ini adalah penelitian kualitatif, penelitian yang menghasilkan deskriptif, dikategorikan sebagai penelitian lapangan, dan teknik yang digunakan adalah Observasi, Dokumentasi, Wawancara, dan Tes. Hasil dari penelitian ini bedasarkan nilai rata-rata yang didapat dari 3 kelas yaitu Pretest 53,53 dan untuk Posttest 58,72. dari hasil ini menunjukkan bahwa penggunaan kitab Qowa'id Imla' karya Abdusslam Muhammad Harun kurang efektif dalam meningkatkan keterampilan menulis Hamzah Washal dan Qatha'. Ada beberapa sebab yaitu, kurangnya dalam memahami materi di dalam kitab tersebut dikarenakan kitab yang dipakai berbahasa Arab, kurangnya perhatian ketika dosen sedang memberikan materi kelas, dan kurangnya waktu dalam memahamkan seluruh materi tentang hamzah washal dan qatha', dan kurangnya latihan menulis selama materi hamzah washal dan qatha'.
\end{abstract}

Kata Kunci: Abdussalam M. Harun, Hamzah dan Menulis 


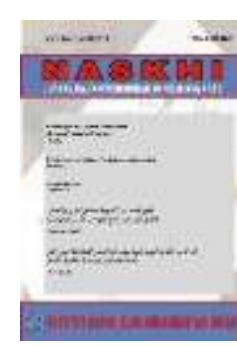

NASKHI

Jurnal Kajian Pendidikan dan Bahasa Arab

Volume 3, No. 2, 2021

ISSN (print) : 2527-5747

ISSN (online) : 2716-3369

Homepage : https://journal.iaimsinjai.ac.id/index.php/naskhi

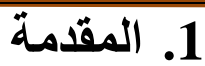

الكتابة هي إحدى أهم المهارات في تدريس اللغة أولى كانت أم أجنبية. الكتابة نفسها, ليست الأنثطة السهلة في أدائها. وقالت سري أوتامي (Sri Utami Subayakto-Nababan) في كتابها

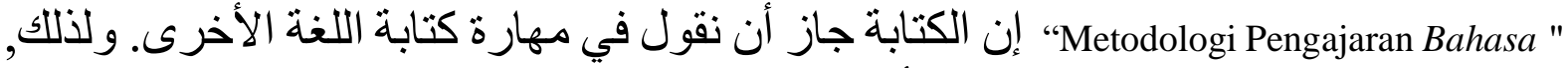
وضع علماء اللغة الكتابة في ترتيب الأخير من مهارات اللغة. بجانب ذللك الكتابة هي التنفيذ

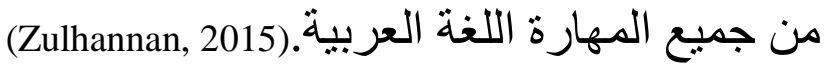

وتعريف مهارة الكتابة هنا هي المهارة في تعبير عن الفكرة و الثنعور في شكل الكتابة

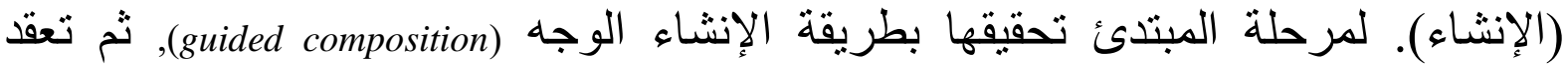
(Zulhannan, 2015).free composition) المو اجهة بالتدر ج, ونحطو إلى الكتابة الحرية الحرية

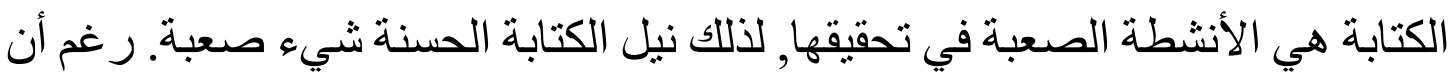
هذه الأنشطة الصعبة, نسنطيع نصل إليها بالجد و الجهـ. (Zulhannan, 2015)

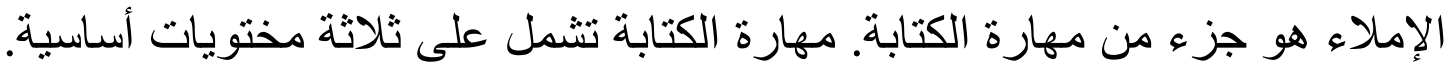

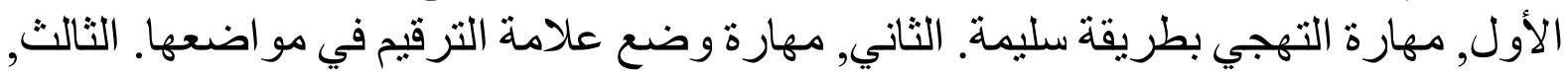
مهارة الرسم الو اضح الجميل للحروف و الكلمة. (Munjiah, 2012)

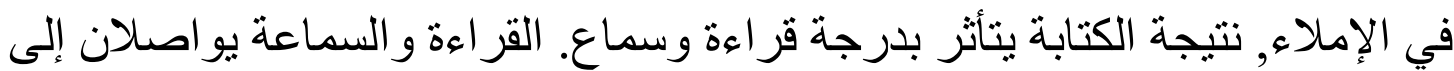

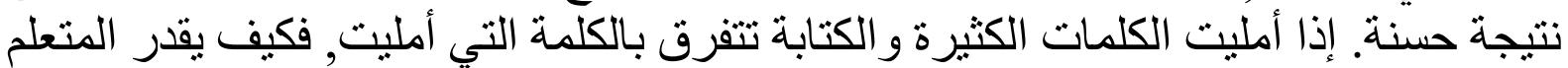

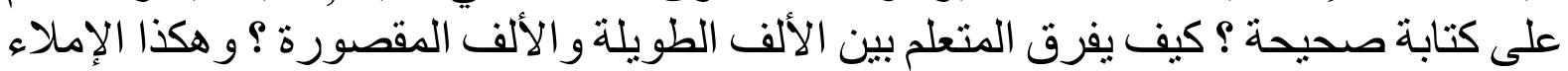
يزود المتعلمين بالمادة عن الكتابة الصحيحة و ينوصل الصل إلى ممارسة.

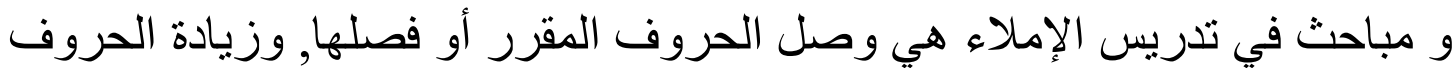

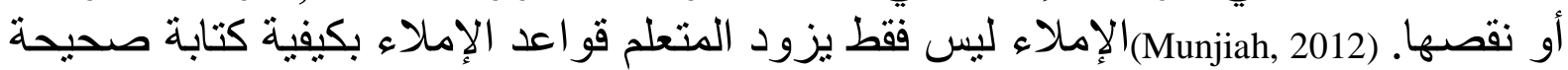

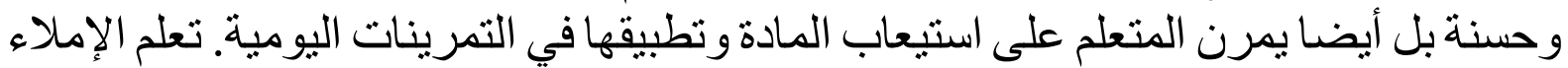

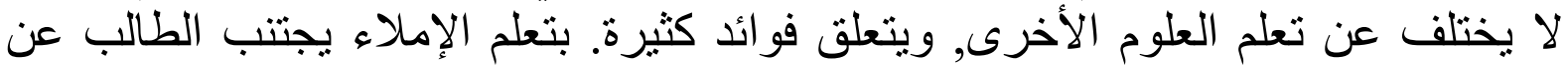

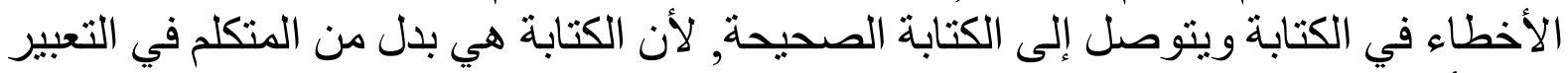

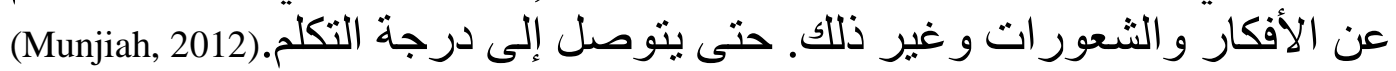

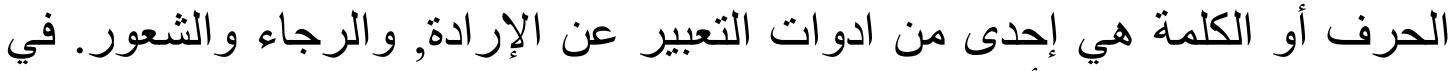

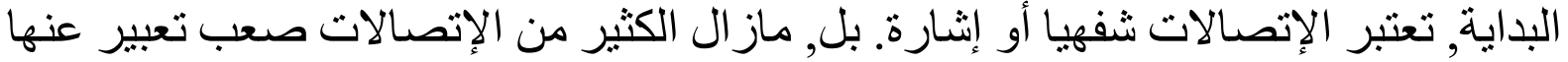

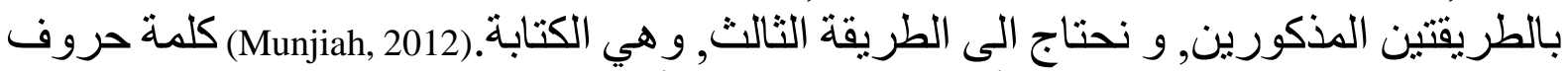

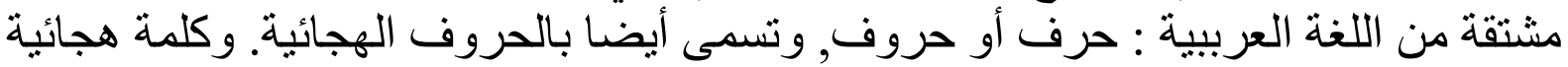

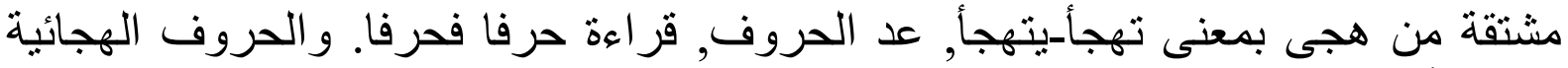
تسمى أيضا بالحروف التهجية. Munjiah, 2012) 


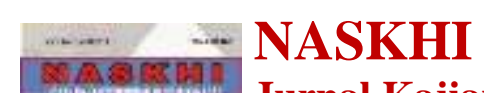

Jurnal Kajian Pendidikan dan Bahasa Arab

Volume 3, No. 2, 2021

ISSN (print) : 2527-5747

ISSN (online) : 2716-3369

Homepage : https://journal.iaimsinjai.ac.id/index.php/naskhi

الهمزة أحد من الحروف الهجائية التي ليس لها شكل نفسها في كتابة العربية كأحرف

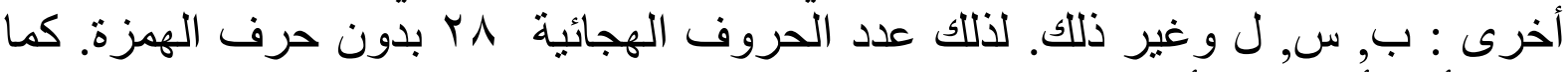

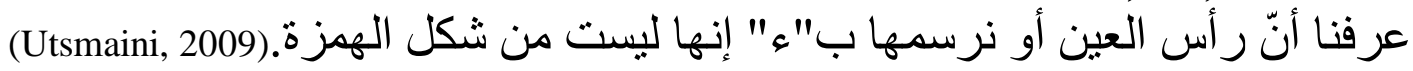

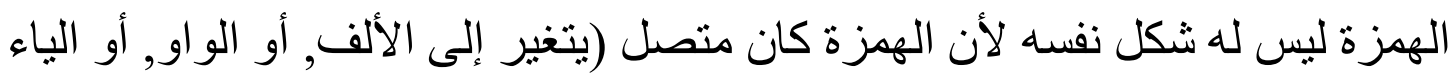

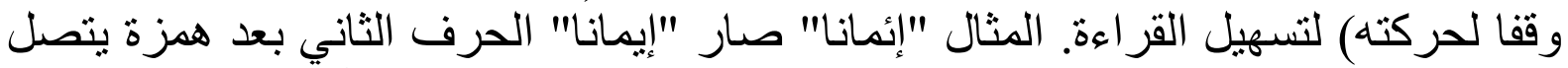

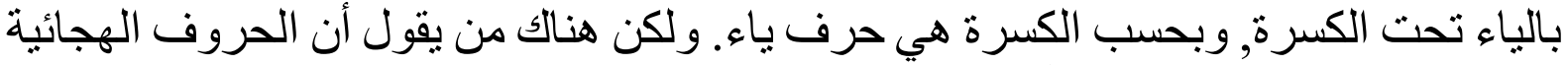

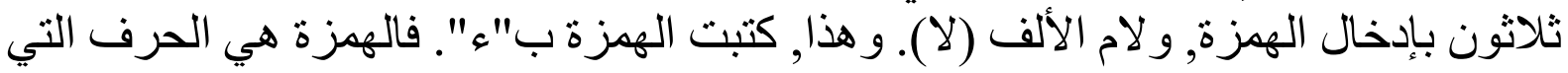

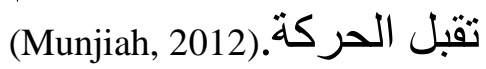

الكتاب المستخدم لطلبة قسم تعليم اللعة العربية في تدريس قو اعد الإملاء السنة الدر اسية

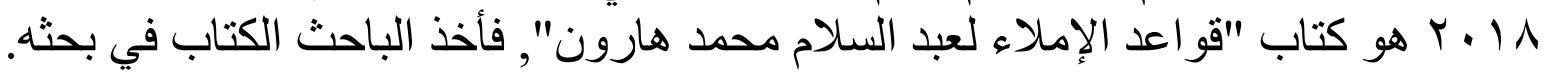

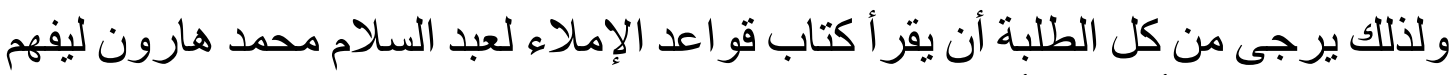

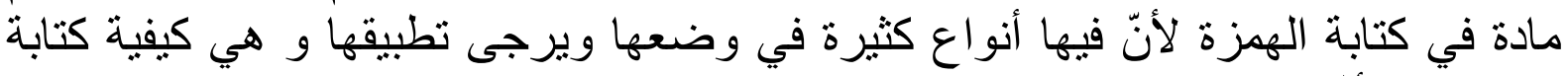

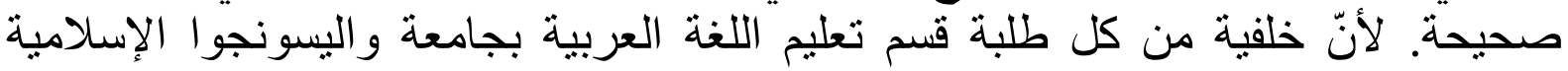

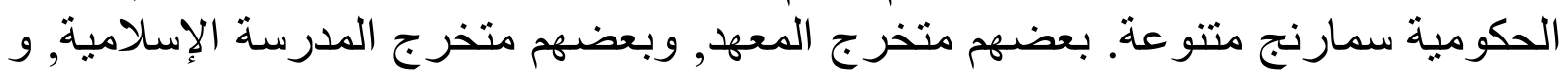
بعضهم من الددرسة العامة التي لا تدرس فيها كيفية كتابة اللغة العربية خصوصا فئلية في تعليم حرف الهمزة إلا قليلا.

رغم أن الطلبات متخرجون في مدارس متنو عة يرجى من كلهم أن يكتب اللغة العربية

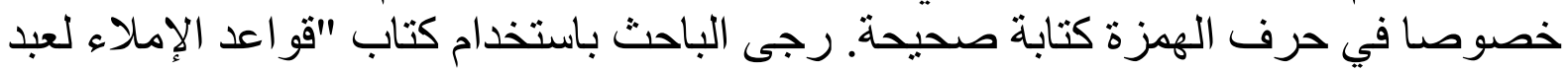
السلام محمد هارون" ارتقت فهم الطلبة كيفية كتابة حرف الهمزة الهنة

\section{وجد الباحث دراسات منعلقة بهذا البحث منها :}

أكبر كورنياو ان (11420018) طالب قسم تعليم اللغة العربية في كلية علم التربية و التذريس جامعة

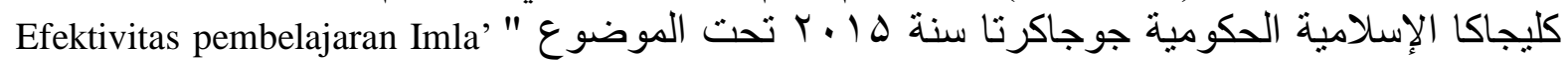
dalam meningkatkan keterampilan menulis kata dalam pembelajaran bahasa Arab siswa kelas XI Madrasah Aliyah Negeri 1 Wates Kulon Progo tahun ajaran 2014-2015", أن نوع هذه البحث هي بحث

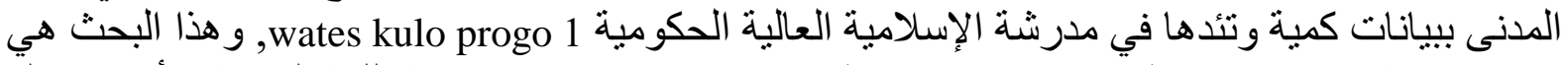

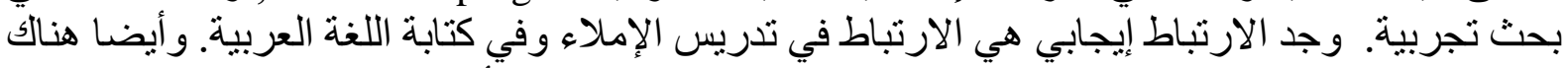

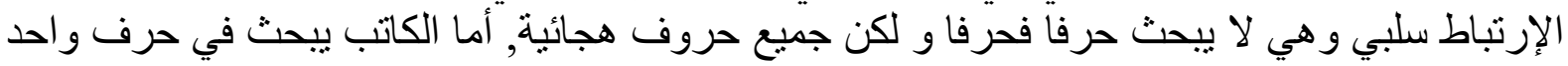
و هو طريقة كتابة حرف الهمزة في كتاب قو اعد الإملاء لعبد السلام محمد هارون هرن.

نور فائزة طالبة قسم تعليم اللغة العربية في كلية علم التربية و التدريس جامعة كليجاكا الإسلامية

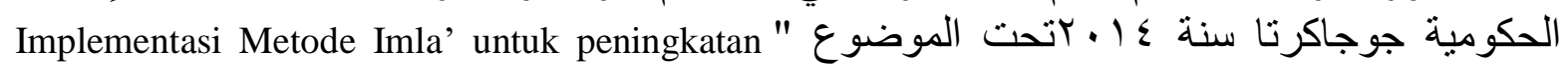
لeaktifan belajar Bahasa Arab siswa kelas VII A MTs Negeri Seyegan العمل الفصول الدراسية وهدف وصف قواعد الإملاء في تدريس اللغة العربية, لترقية النشاط في تعلم 


\section{- NASKKI}

Jurnal Kajian Pendidikan dan Bahasa Arab

Volume 3, No. 2, 2021

ISSN (print) : 2527-5747

ISSN (online) : 2716-3369

Homepage : https://journal.iaimsinjai.ac.id/index.php/naskhi

اللغة العربية لطلاب. توجد في هذا البحث تسوية في تطبيق قو اعد الإملاء, لترقية النشاط طلاب في الفصل,

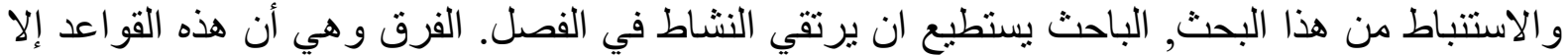

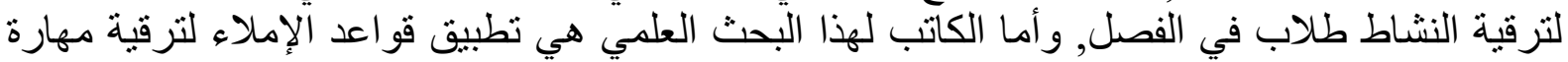

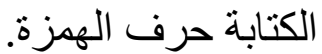

دوكتور هانية (Dr. Haniah, Lc. M.A.) في كلية دعوة والإتصالات جامعة الإسلامية الحكومية

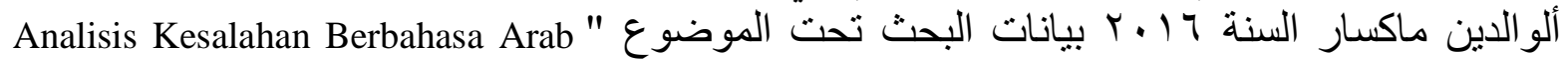
الإن Skripsi Mahasiswa Bahasa dan Sastra Arab UIN Alauddin Makassar الأخطاء كتابة حروف الهمزة في بحث علمي للطلبة قسم اللغة والأدب العربية في جامعة الإسلامية

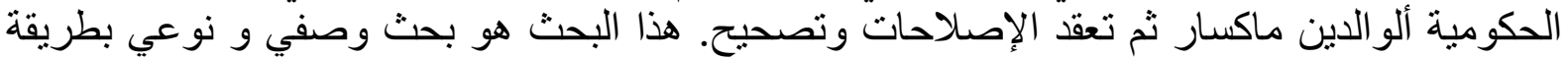

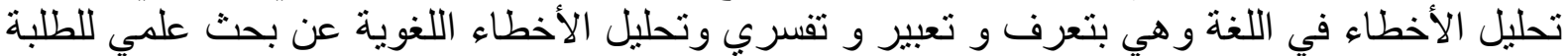

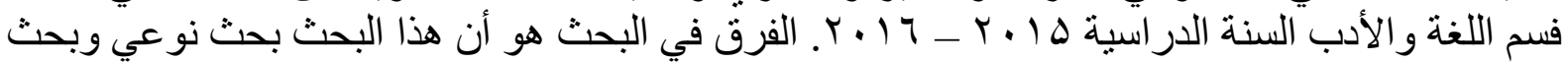

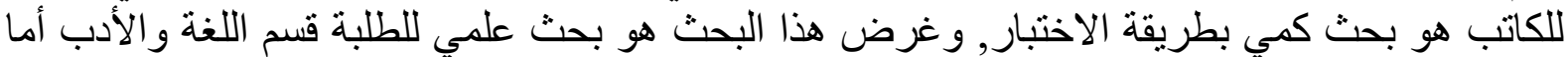
غرض البحث للكاتب هو كتاب قو اعد الإملاء لعبد السلام محمد هارون. هون.

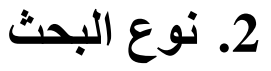

نوع هذا البحث بحث نوعي. و هو البحث الذي بحصل على البيانات الوصفية. و من من نو عه يستطيع أن يسمى بالبحث الميداني, هو البحث الذي يعقد مكثفا, و مفصلا: و و متعمقا إلى

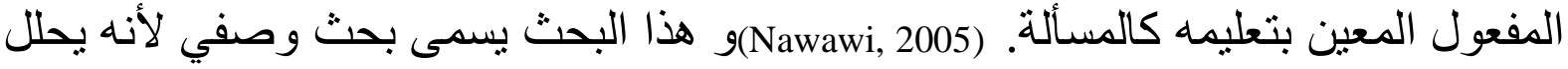
و يقدم البيانات منظما عن المفعول حقا. (Azwar, 1999)

رأى هيدر النووي (Hadari Nawawi)في موليوع (Moleong) أن البحث النوعي هو عملية

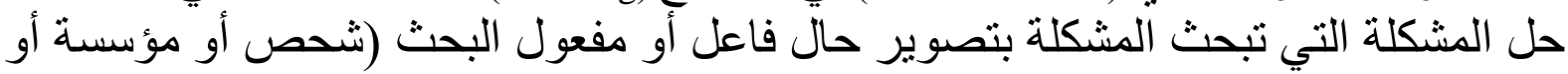
مجتمع أو غير ذلك) في هذا الحال مناسبا للبيانات الموجودة. (Lexy, 2002)

استخدم الباحث المنهج النوعي في هذا البحث, يعني المنهج الذي يؤكد على تعلم قو اعد اعداء الإملاء باستخدام كتاب قو اعد الإملاء لعبد السلام محمد هارون عن مادة كتابة حرف الف الهزية

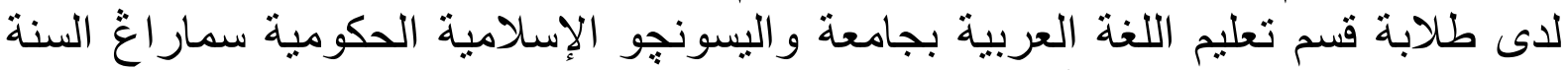

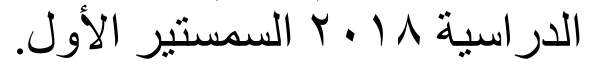

2 2.1 مكان و وقت البحث

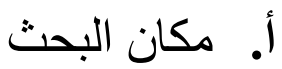

فعل الباحث هذا البحث بجامعة واليسونجو الإسلامية الحكومية سمار اغٔ. بشارع البروفسور الدوكتور هامكا تمباكجي عالبان, مدينة سمارنج, جاوى الوسطى. ب. بوقت البحث:

أجرى هذا البحث من التاريخ | 1 أوكتوبر إلى بr نوفمبير السنة م | ب . 


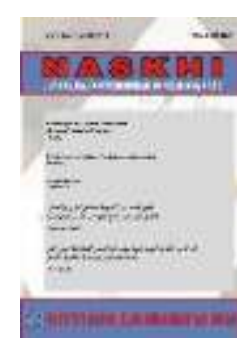

\section{NASKHI}

Jurnal Kajian Pendidikan dan Bahasa Arab

Volume 3, No. 2, 2021

ISSN (print) : 2527-5747

ISSN (online) : 2716-3369

Homepage : https://journal.iaimsinjai.ac.id/index.php/naskhi

مصادر البيانات

البيانات هي كلّ شيء مكتوب. (Darwis, 2014) ينقسم إلى اثتين هما بيانات رئيسيّة و بيانات

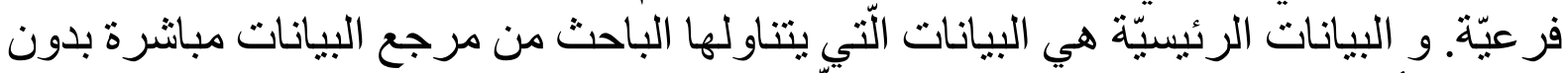

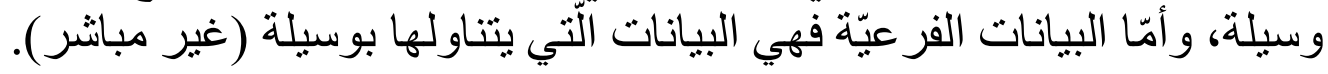

وفي هذا البحث، استعمل الباحث بياناتا رئيسيّة و بياناتا فرعيّة. أمّا البيانات الرّئيسيّة

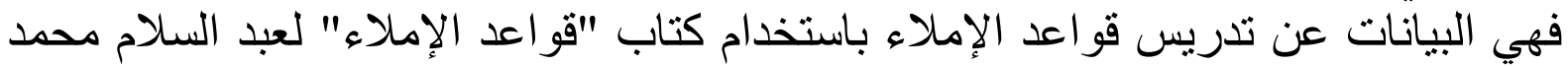

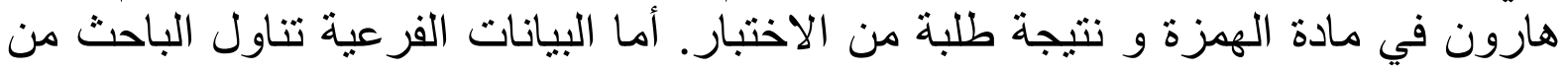

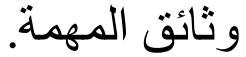

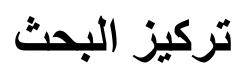

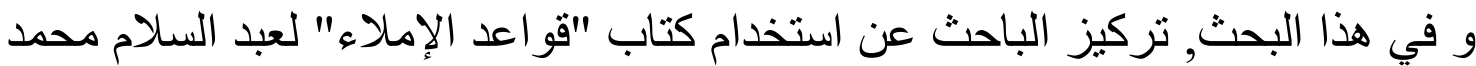

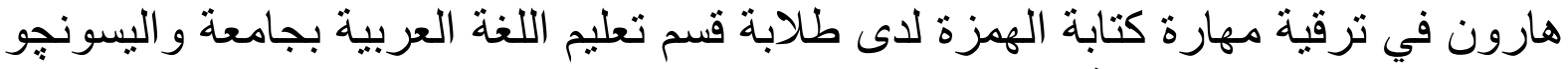

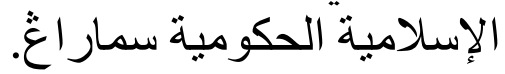

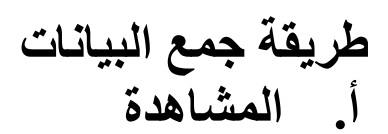

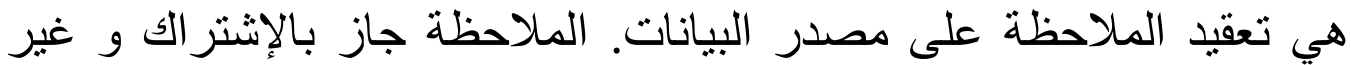

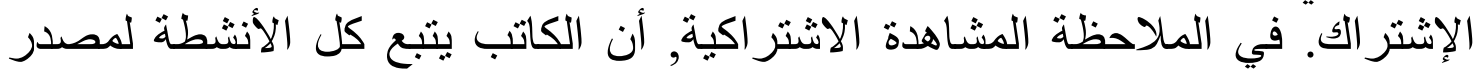

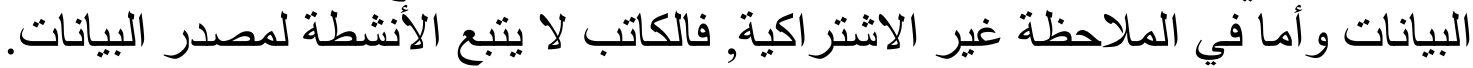

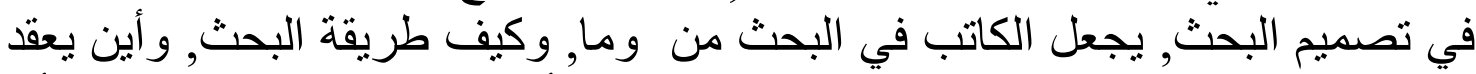

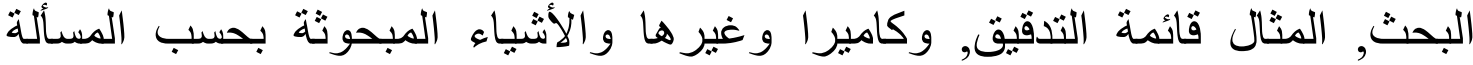

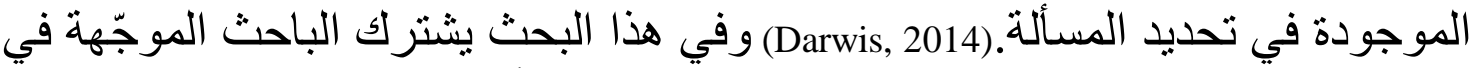
محاضرة درس قو اعد الإملاء لمشاهدة كيفية إلقاء المادة أو كيفية إجر اء تللك المحاضرة.

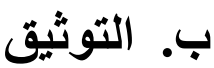

تطبيق هذه الطريقة بجمع وتحليل عدة من الوثائق التي تتعلق بمسألة البحث. في

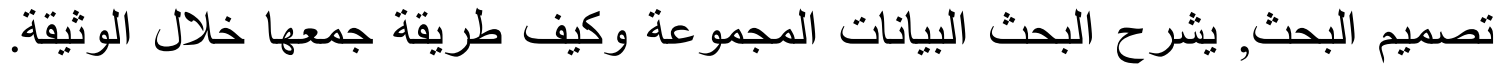
(Darwis, 2014)

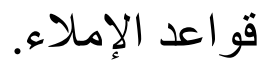

ت. ت. المقابلة

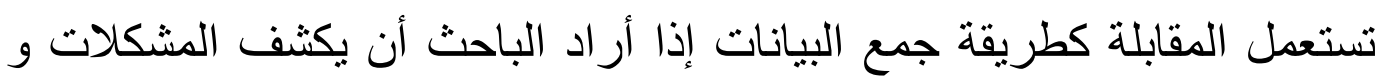

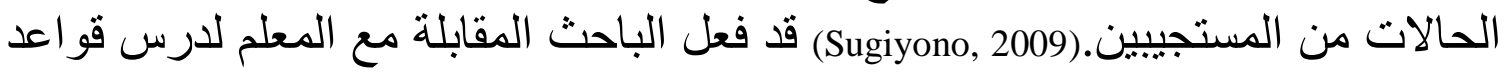

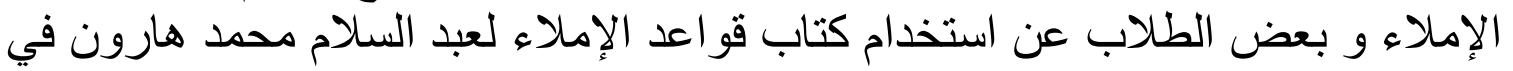




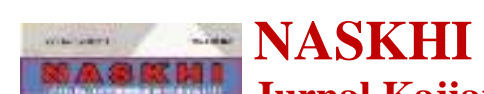

Jurnal Kajian Pendidikan dan Bahasa Arab

Volume 3, No. 2, 2021

ISSN (print) : 2527-5747

ISSN (online) : 2716-3369

Homepage : https://journal.iaimsinjai.ac.id/index.php/naskhi

ترقية مهارة كتابة الهمزة لاى طلبة قسم تعليم اللغة العربية بجامعة و اليسونجو الإسلامية الحكومية سمار اج.

ث. الاختبار

الاختبار أداة لجمع البيانات وهو جمع الأسئلة أو تمرينات تستعمل لقياس المهارة

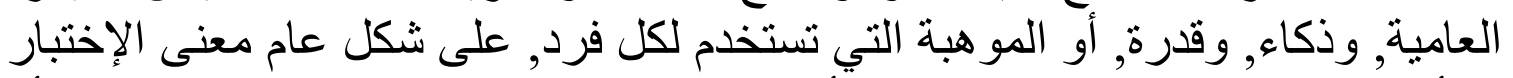

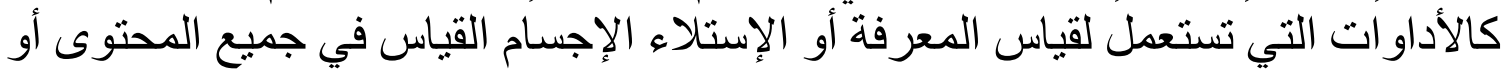

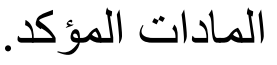

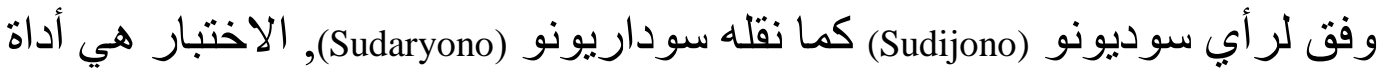

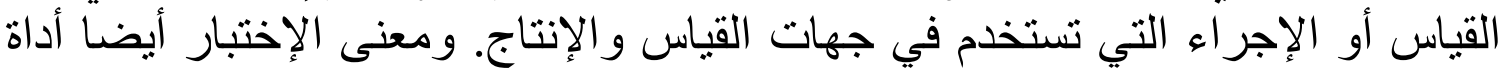

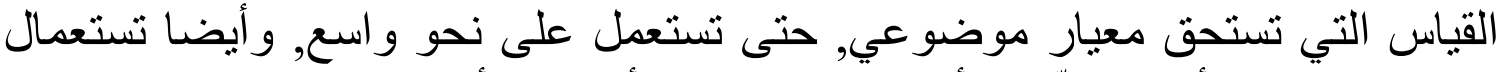

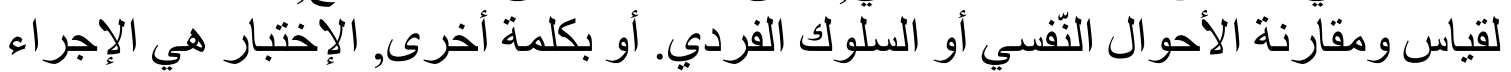

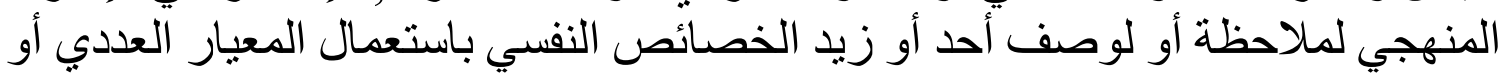
نظام الفئة. (Sudaryono, 2017)

في هذا البحث الباحث يستعمل طريقة الإختبار لتناول البيانات عن مادة الهمزة في كتاب قو اعد الإملاء لعبد السلام محمد هارون.

طريقة تحليل البيانات

وفي البحث النّوعيّ، يُنتاول البيانات من كلّ مرجع، باستعمال طريقة جمع البيانات

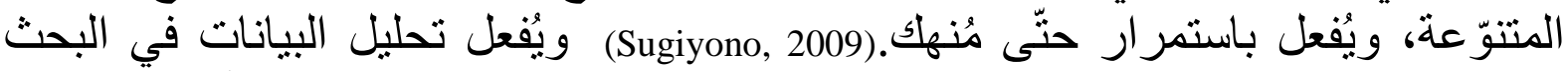

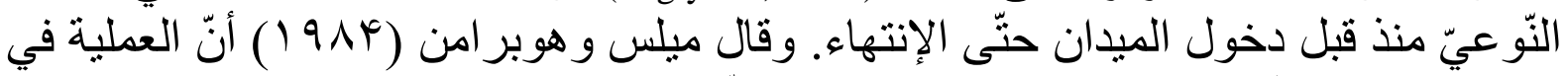

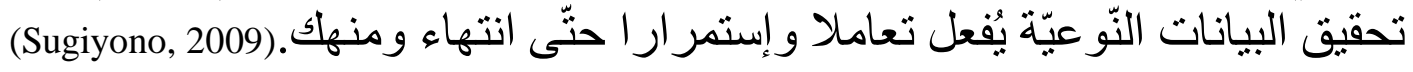
وفي هذا البحث، البيانات التي يناوله حلّل البيانات باستعمال طريقة الوصفيّة، لأنها

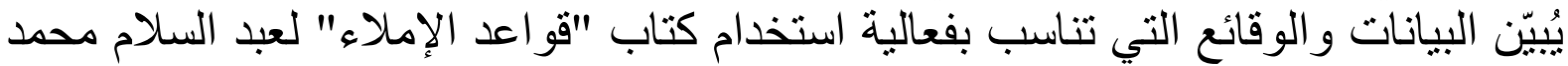

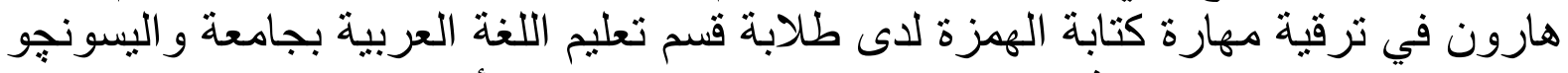

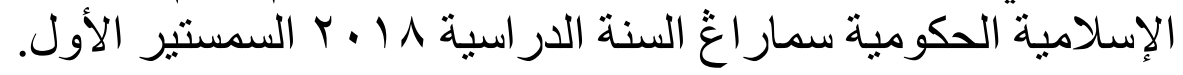

$$
\text { و أمّا طرق تحليل البيانات منها: }
$$

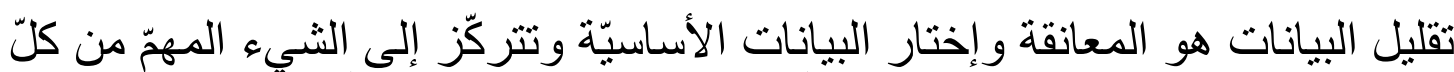

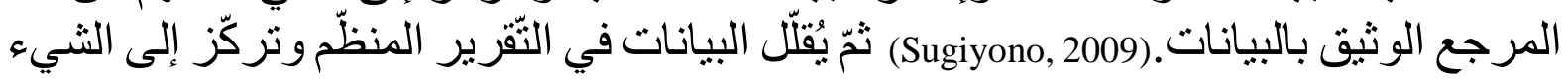
الذي يناسب بفعالية استخدام كتاب "قو العد الإملاء" لعبد الستلام محمد هارون في ترقية مهارة التئ

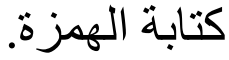




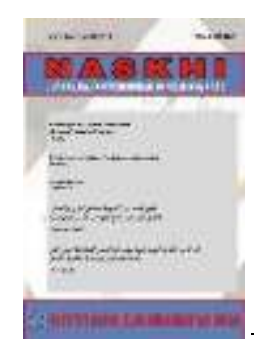

\section{NASKHI}

Jurnal Kajian Pendidikan dan Bahasa Arab

Volume 3, No. 2, 2021

ISSN (print) : 2527-5747

ISSN (online) : 2716-3369

Homepage : https://journal.iaimsinjai.ac.id/index.php/naskhi

\section{ب. معانقة البيانات}

معانقة البيانات هي يعانق الباحث البيانات في خلاصة و فكرة أساسيّة ثمّ يُفصَّل وصفيّا

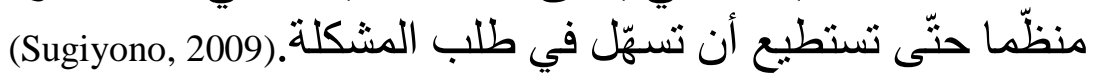
ت. ت ت الاختمام البيانات

اختمام البيانات هو يطلب الباحت البات معنى البيانات التي تُجمع دقيقا. والحاصل من هذا

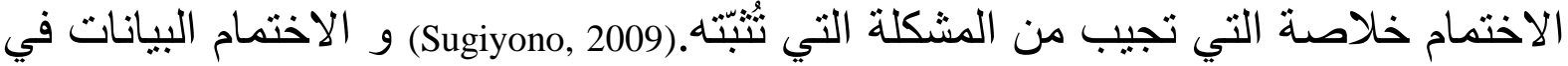
هذا البحث هي استخدام كتاب "قو اعد الإملاء" لعبد السلام محمد هارون في ترقية مهارة كتابة التيات

\section{6}

تجريبة صدق البيانات في البحث النّوعيّ هو:

أ. تجريبة الصو اب (Uji Kreadibilitas)

يُستعمل بطول المر اقبة وتزداد حماسة في البحث و إختلاط ومناقثة بصاحب وتحليل

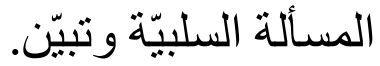

ب. تجريبة الإنتقال (Uji Transferability)

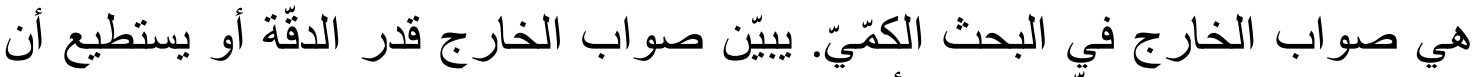

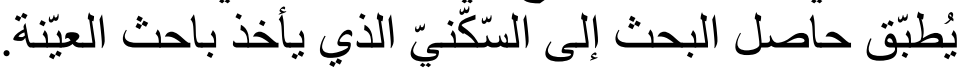

ت. تجريبة المحدّد (Uji Dependability)

في البحث النّو عيّ يُستعمل هذه التجريبة بافعال التّققيق إلى جميع البحث

\section{3. توصيف البيانات وتحليلها}

\section{1}

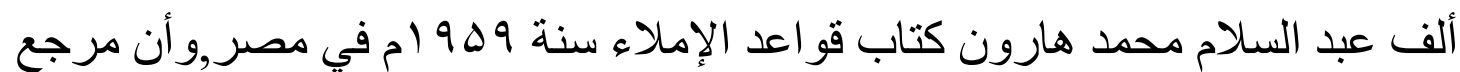

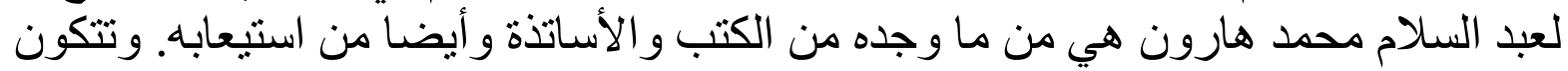

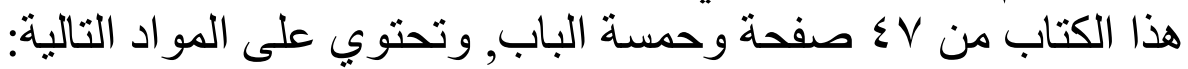

- - الباب الأول : الهزةة أول الكلمة, الهمزة آخر الكلمة, الهمزة وسط الكلم

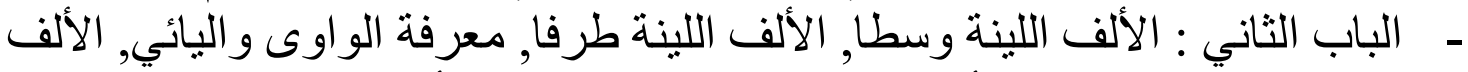

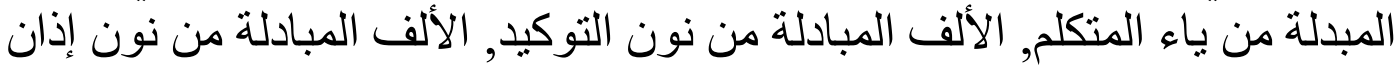

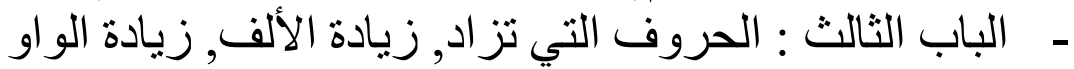




\section{NASKHI}

Jurnal Kajian Pendidikan dan Bahasa Arab

Volume 3, No. 2, 2021

ISSN (print) : 2527-5747

ISSN (online) : 2716-3369

Homepage : https://journal.iaimsinjai.ac.id/index.php/naskhi

- - الباب الرابع : الحروف التي تنقص, نقص الألف أو لا, نقص الألف وسطا, نقص

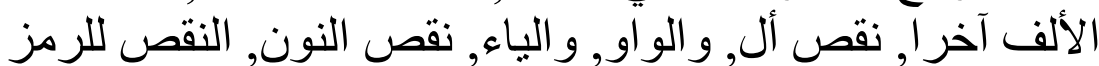

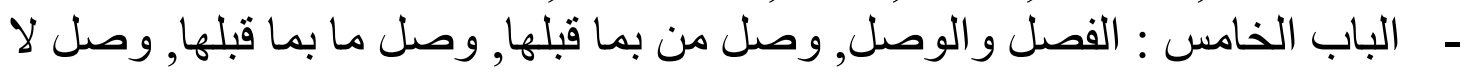

بما قبلها

-

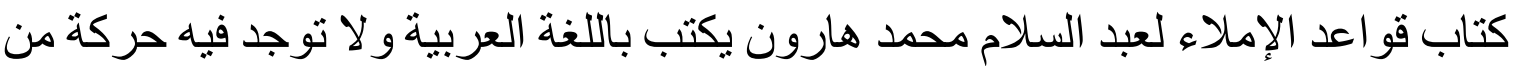

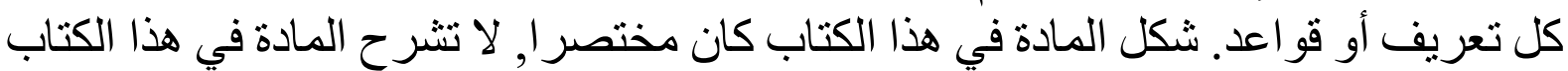

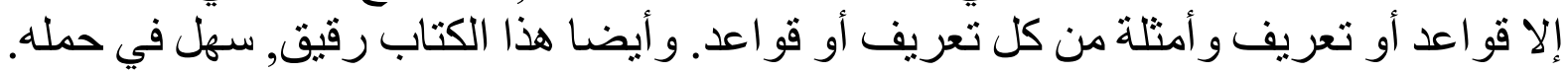

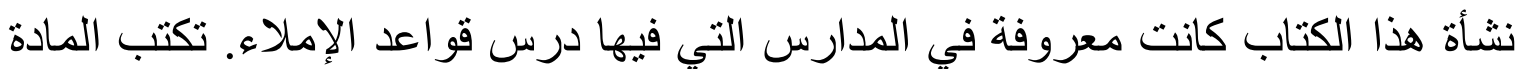

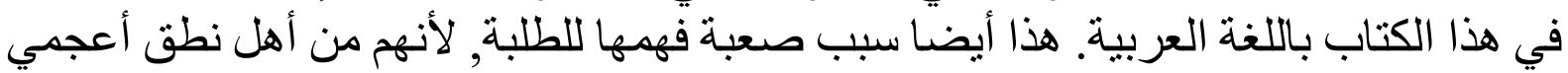
ولَّيس من نطق العربي. لذلك أن يترجم أو لا لسهولة فهم المادة في هذا الكتاب.

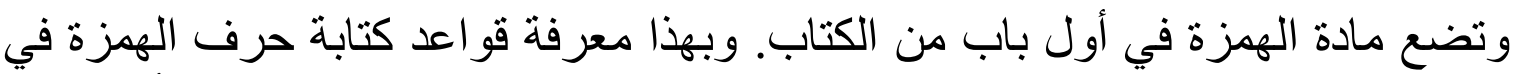

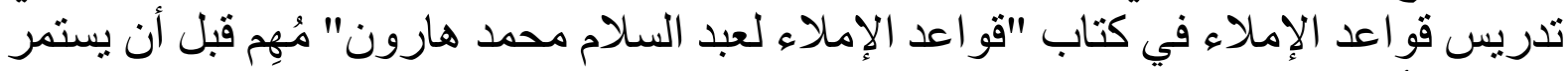

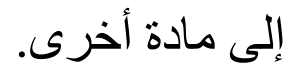

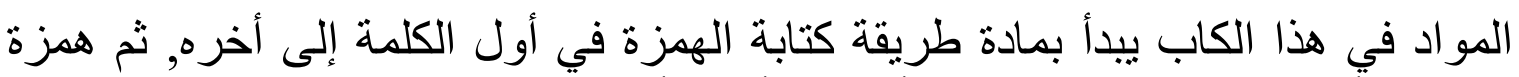

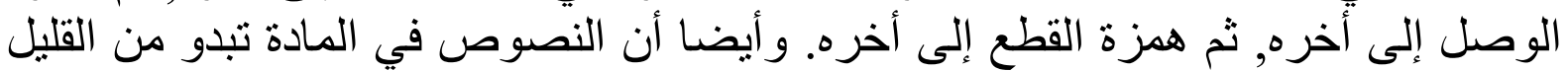

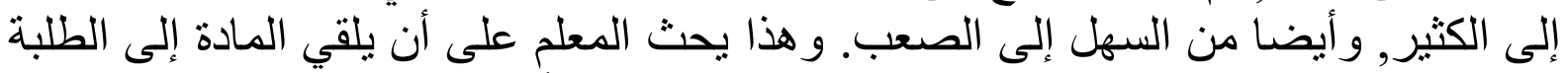

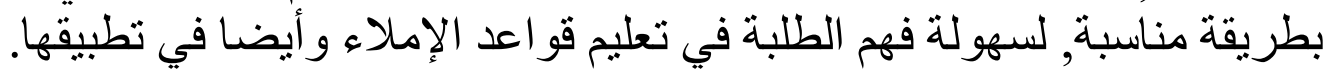

كان هذا الكتاب يستخدم في تدريس قواعد الإملاء في قسم تعليم اللغة العربية بجامعة الإنة

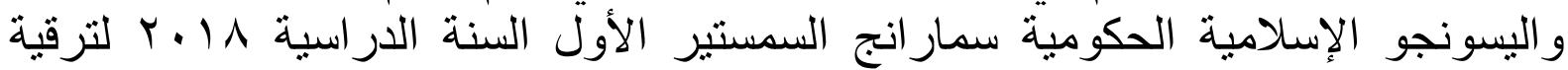
مهارتهم في القراءة وخصوصا لسهولة فهم طريقة الكتابة العربية.

و إذا كان هذا الكتاب يستخدم في المدارس الأخرى التي فيها نادر تعويد الطلبة على استخدام

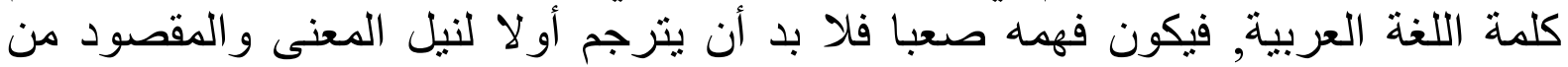
محتوياته.

فإذا كان هذا الكتاب مقررا في درس قو اعد الإملاء في الجامعة من ناحية نظرية فإنإنها

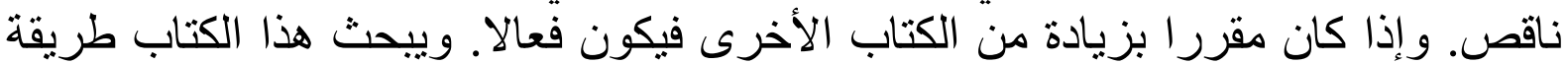

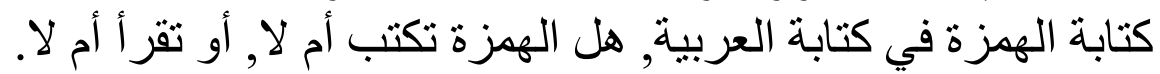




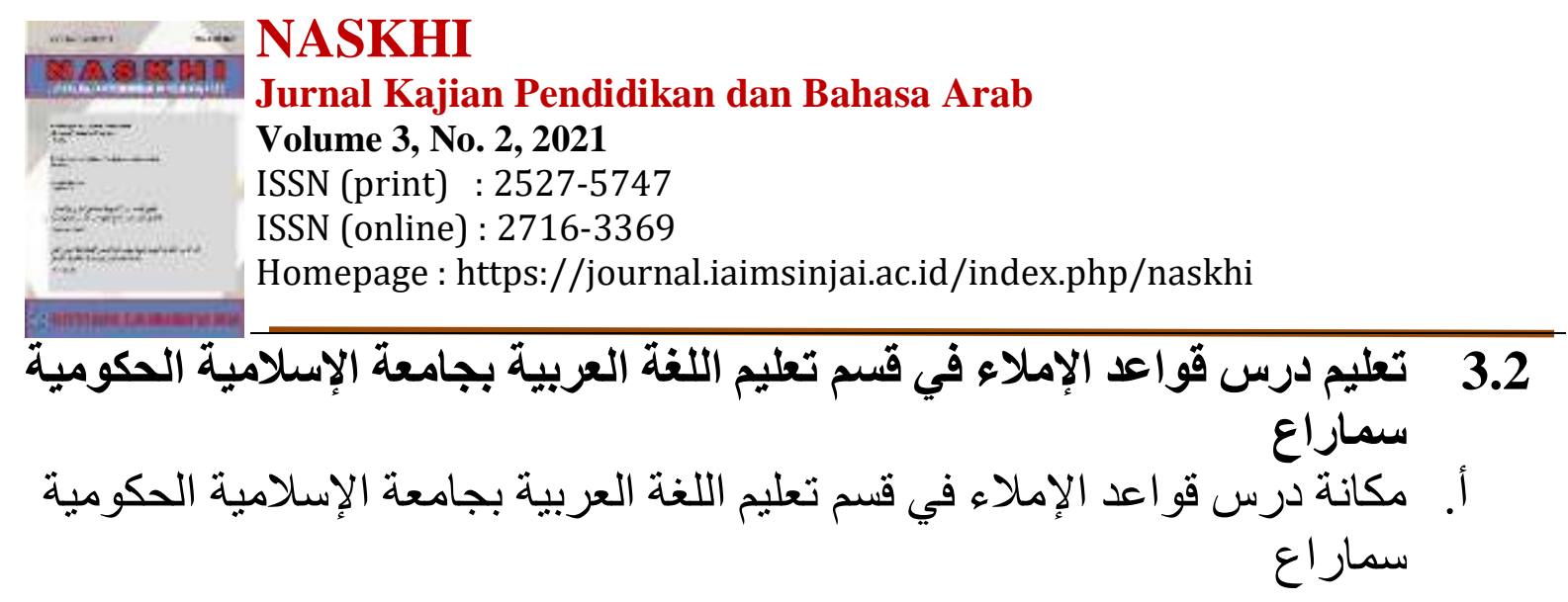

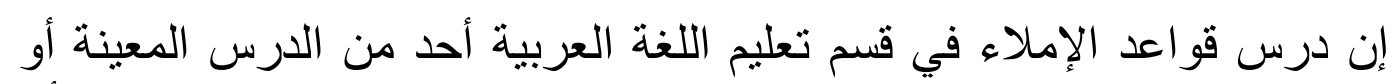

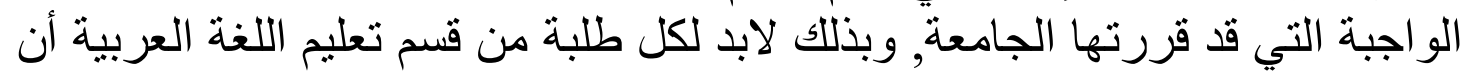
يأخذ هذا الدرس.

و الغرض في تدريس قو اعد الإملاء في مادة الهمزة في أول الكلمة هو تزويد كل

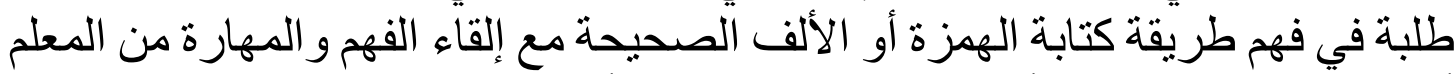

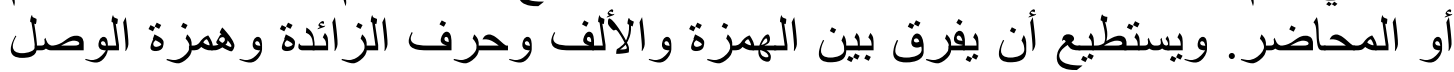

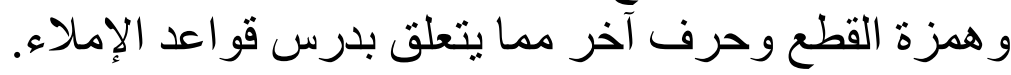

وأيضا في طريقة قر اءة وفهم النص الذي ليس هناك الحركة. فإن تعليم الحركة

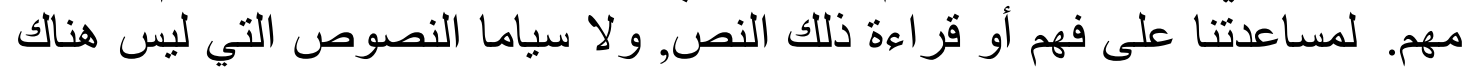

ب. أحو ال المحاضر و الطلبة

عدد المحاضر لدرس قو اعد الإملاء في قسم تعليم اللغة العربية بحامعة الإسلامية

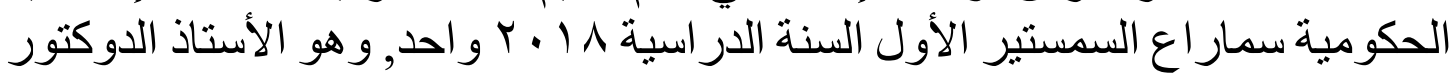
سجاعي الماجيستير, متخرج في: المئر

جامعة و اليسونجو الإسلامية الحكومية سمار اع في قسم التعاليم الإسلامية في كلية علم التربية و التدريس

جامعة شريف هدية الله الإسلامية الحكومية جاكارتا في قسم أدب اللغة العربية جامعة شريف هدية الله الإسلامية الحكومية جاكارتا في قسم أدب اللغة العربية وقد صار محاضر ا منذ السنة 1997 حتى الأن, ويعلم درس قو اعد الإملاء في السنة م1 • ب.

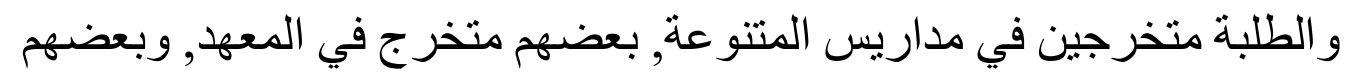

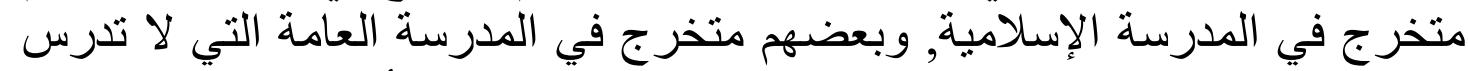

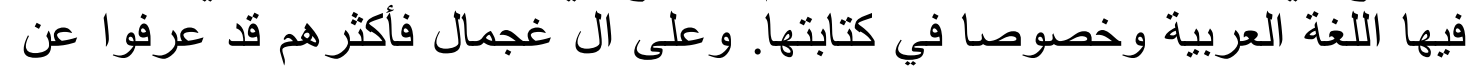

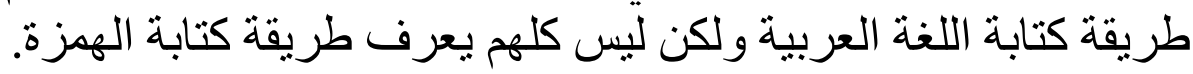




\section{- NASKKI}

Jurnal Kajian Pendidikan dan Bahasa Arab

Volume 3, No. 2, 2021

ISSN (print) : 2527-5747

ISSN (online) : 2716-3369

Homepage : https://journal.iaimsinjai.ac.id/index.php/naskhi

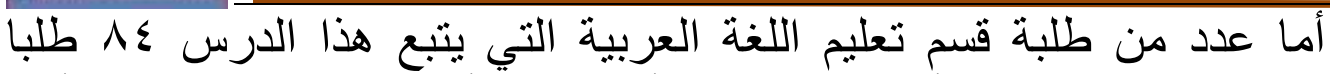
وينقسمون إلى ثلاثة فصول "أ" و "ب" و "ج. أكثر هم قد أخذوا درس الصند الصرف الأول ودرس الصرف الثناني.

$$
\text { ت. مصادر في تعليم كتابة همزتي الوصل و القطع }
$$

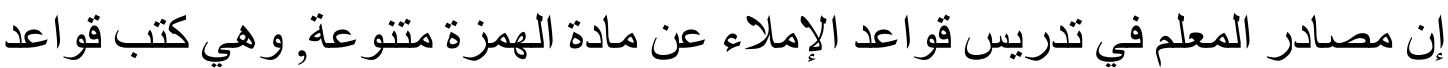

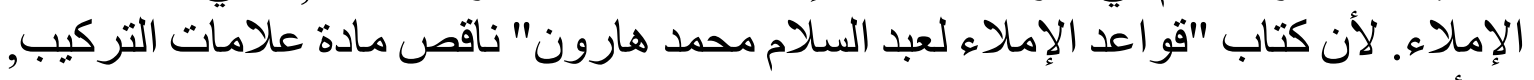

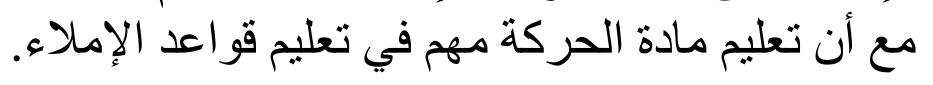

ولذلك جمع المعلم المادة من الكتب الكثيرة عن قو اعد الإملاء يعني لسهولة للطلبة فهرم

$$
\text { مادة الهمزة وترقية مهارتهم في كتابة العربية. }
$$

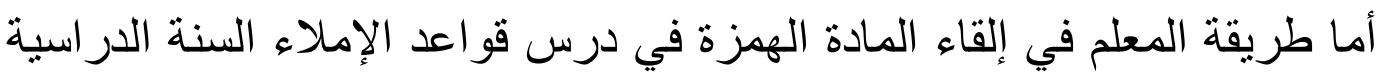

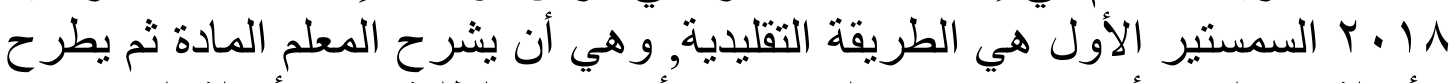

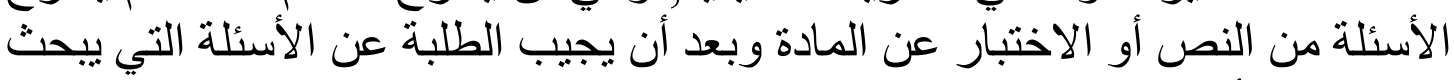

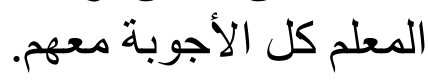

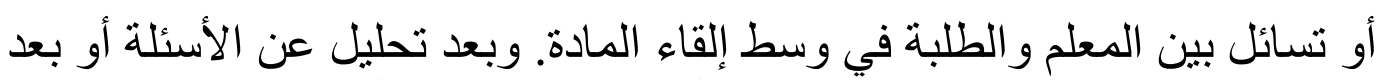

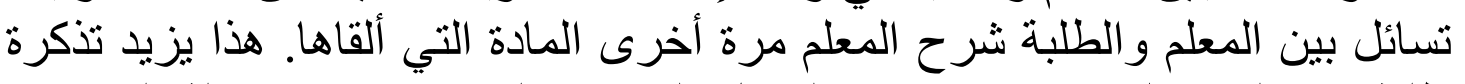

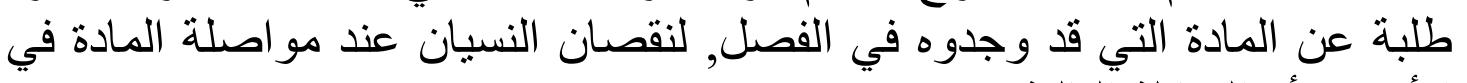
الأسبوع أو المقابلة التالية.

$$
\text { ج. الوسائل في تدريس قو اعد قو اعد همزتي الوصل و القطع }
$$

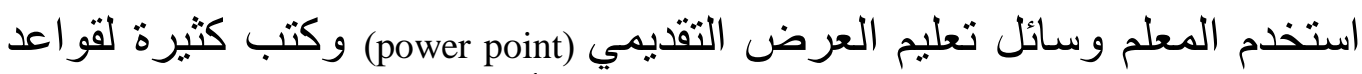

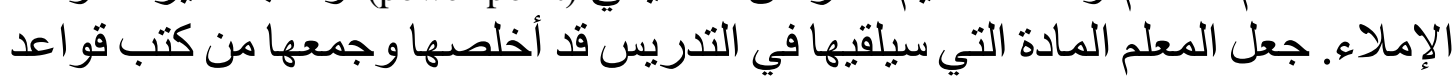
الإملاء الكثبرة عن مادة همزتي الوصل و القطع لسهولة فهم الطلبة.

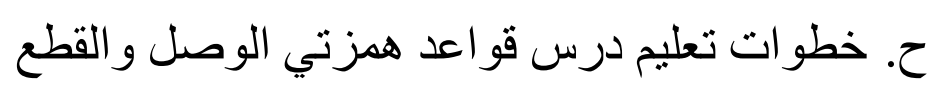

الخطوات في تعليم درس قو اعد الإملاء لقسم تعليم اللغة العربية سمستير الأول

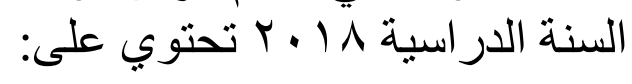

الأول, يدخل المعلم الفصل بسلام ويبدأ التعليم بالدعاء معا

الثاني, يسئل المعلم الطلبة عن المادة السابقة لتعليقها بالمادة الجديدة التي سيلقيها

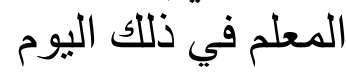




\section{- NASKH}

Jurnal Kajian Pendidikan dan Bahasa Arab

Volume 3, No. 2, 2021

ISSN (print) : 2527-5747

ISSN (online) : 2716-3369

Homepage : https://journal.iaimsinjai.ac.id/index.php/naskhi

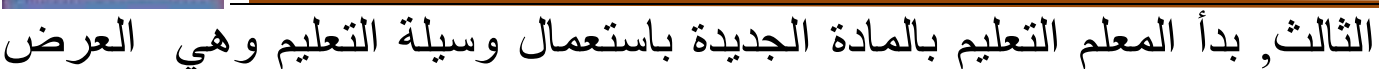

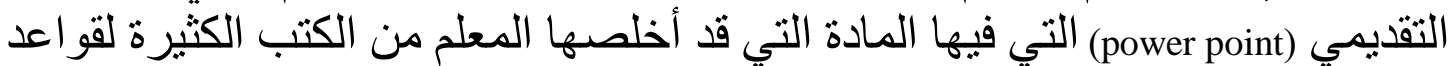

الر ابع, فيشرح المعلم المادة كاملا, وهي مادة عن طريقة كتابة الهززة

الخامس, بعد أن شرح المعلم المادة التي ألقاها في ذلك اليوم يسأل المعلم عن المادة

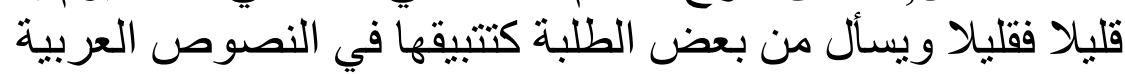

السادس, بعد إعطاء السؤال من المعلم تجري المناقشة بين الطلبة و المعلم عن السؤال

لبحث الأجوبة الصحيحة

السابع, بعد أن يجد الطلبة الأجوبة الصحيحة يحلل المعلم معهم الأسئلة و الأجوبة

الثامن, يشرح المعلم المادة مرة أخرى لتقوية فهمها لدى الطلبة

التاسع, يختم المعلم المادة السليمية بحث على الطلبة قر اعة الكتاب وتطبيق المادة الدرس وس

المدروسة خارج وقت المعم المادة المطرة

العاثر, يختتم المعلم الدرس بالدعاء و السلام

تحليل البيانات

3.3

بعد تمام تعليم المعلم الطلبة قو اعد همزتي الوصل و القطع, قام الباحث باختبار الطلبة هذه المادة في شكل الأسئلة من ذلك الاختبار وجد الباحث النتيجة المتوسطة من الطلبة, وهي فيما يلي :

\begin{tabular}{|c|c|}
\hline القيمة المتوسطة & الفصل \\
\hline$\Delta V, q \leqslant Y T$ & الفصل "أ" \\
\hline$\Delta Y, \leqslant \Delta \leqslant \Delta$ & الفصل "ب" \\
\hline $7 \Delta, \vee \vee \vee \wedge$ & الفصل "ج" \\
\hline$\Delta r, Y Y \Delta I$ & الجملة \\
\hline
\end{tabular}




\section{- NASKKII}

Jurnal Kajian Pendidikan dan Bahasa Arab

Volume 3, No. 2, 2021

ISSN (print) : 2527-5747

ISSN (online) : 2716-3369

Homepage : https://journal.iaimsinjai.ac.id/index.php/naskhi

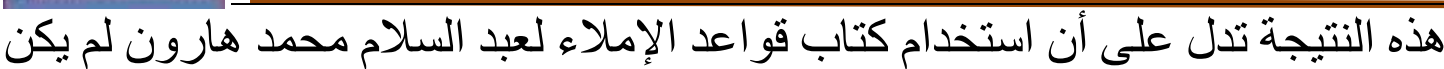

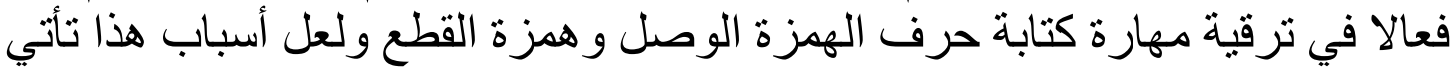
sن

أ. مشكلة فهم الطلبة محتويات الكتاب المكتوب باللغة العربية لقلة مهارتهم في قر اعة

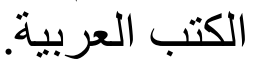
ب. من الملاحظة أو المشاهدة الباحث في الفصل أن الإهتمام طلبة بالتعليم ناقص, هذا

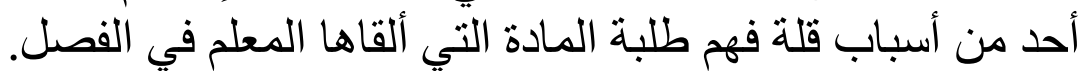

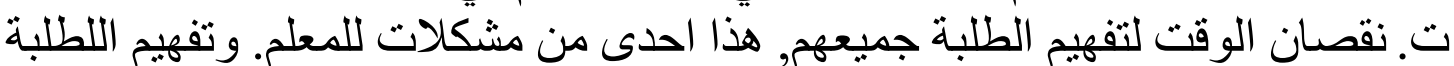

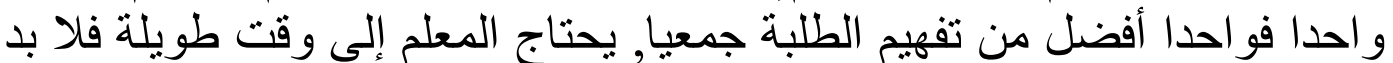
فيه أن يعرف المعلم أحوال كل الطلبة فرديا نحو المادة التي ألقاها المعلم.

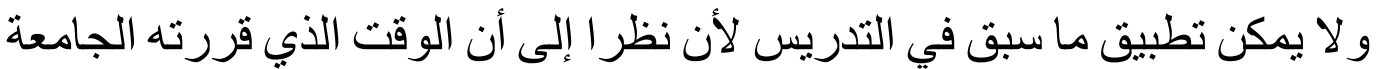

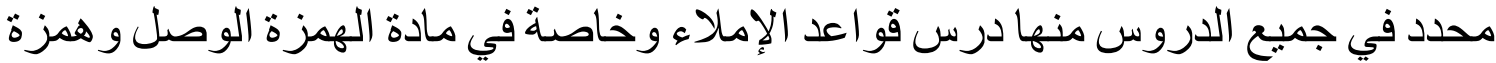

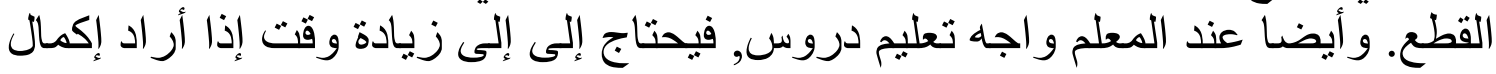

فهم الطلبة فهما صحيحا.

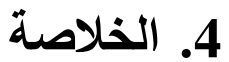 \\ - 2 - 2 4}

من الاختبار الذي عقدها الباحث نحو طلبة قسم تعليم اللغة العربية في تعليم

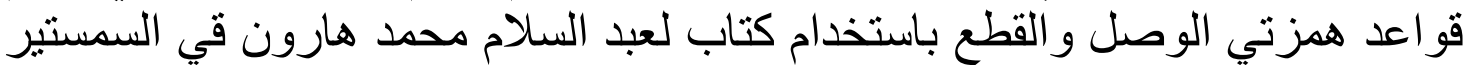

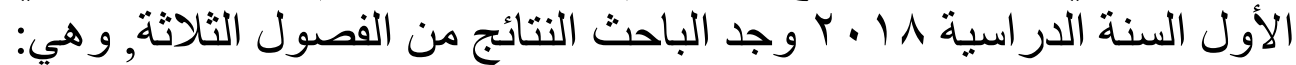

نتيجة في اختبار قبلي

\begin{tabular}{|c|c|}
\hline القيمة المتوسطة & الفصل \\
\hline$\Delta \leqslant, \Delta l$ & فصل "أ" \\
\hline$\Delta \Delta, \Delta r$ & فصل "ب" \\
\hline$\Delta 9, \Delta 7$ & فصل "ج" \\
\hline$\Delta r, \Delta r$ & جميع الفصول \\
\hline
\end{tabular}




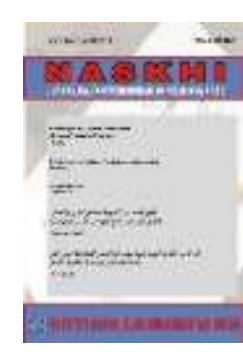

\section{NASKHI}

Jurnal Kajian Pendidikan dan Bahasa Arab

Volume 3, No. 2, 2021

ISSN (print) : 2527-5747

ISSN (online) : 2716-3369

Homepage : https://journal.iaimsinjai.ac.id/index.php/naskhi

$$
\text { نتيجة في اختبار بعدي }
$$

\begin{tabular}{|c|c|}
\hline القيمة المتوسطة & الفصل \\
\hline$\Delta V, q \leq$ & فصل "أ" \\
\hline$\Delta r, \leqslant \Delta$ & فصل "ب" \\
\hline $7 \Delta, V V$ & فصل "ج" \\
\hline$\Delta \Lambda, V Y$ & جميع الفصول \\
\hline
\end{tabular}

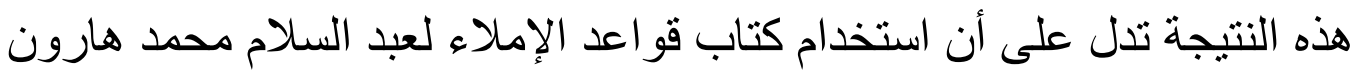

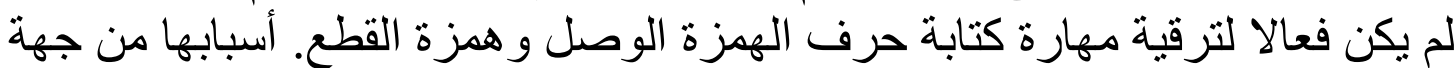

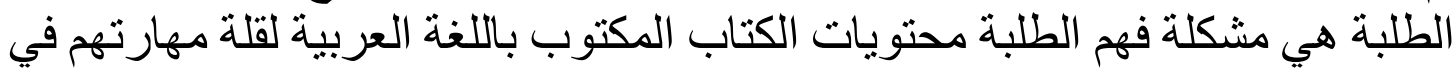

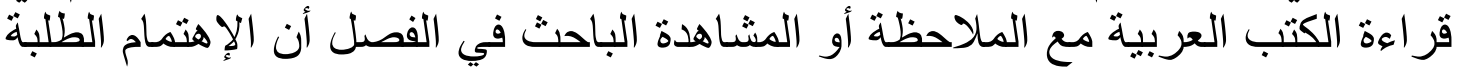

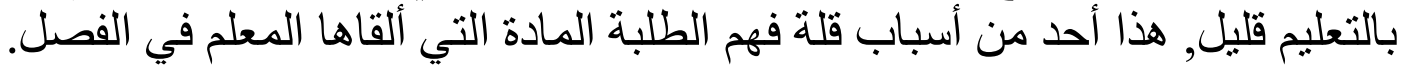

من جهة الوقت, نقصان الوقت لتفهيم الطلبة جميعهم, وتفهيم الطلبة واحدا فو احدا

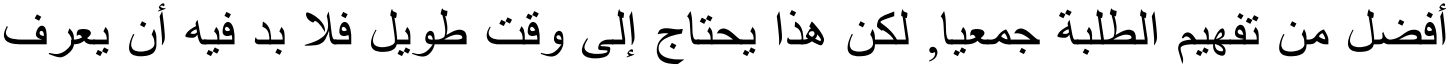

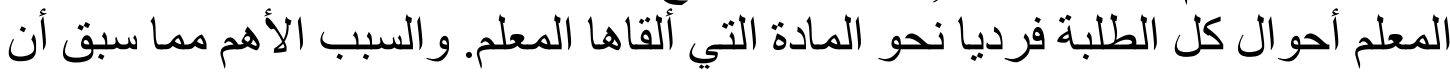
الطلبة لم يطبقو ا قو اعد همزتي الوصل ورديا نحادة القطع في الكتابة العربية إلا قليلا.

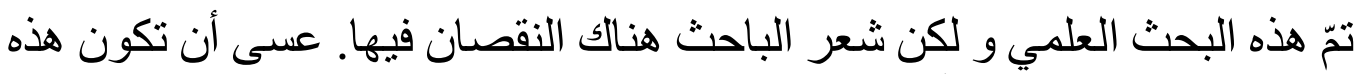

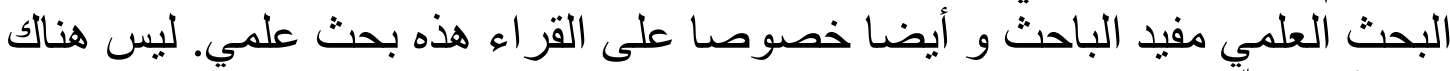
كلمة أخر إلاّ كلمة حمدلله و الثنكر علينا. 


\section{NASKHI}

Jurnal Kajian Pendidikan dan Bahasa Arab

Volume 3, No. 2, 2021

ISSN (print) : 2527-5747

ISSN (online) : 2716-3369

Homepage : https://journal.iaimsinjai.ac.id/index.php/naskhi

\section{Daftar Pustaka}

Azwar, S. (1999). Metode Penelitian, cet, ket-2. Yogyakarta: Pustaka Pelajar Offset.

Darwis, A. (2014). Metode Penelitian Pendidikan Islam Pendekatan Kuantitatif dan Kualitatf. Jakarta: Rajawali Pers.

Lexy, J. M. (2002). Metodologi penelitian kualitatif. Bandung: Remaja Rosdakarya.

Munjiah, M. (2012). Kaidah-kaidah imla': Teori dan praktik. UIN-Maliki Press.

Nawawi, H. H. (2005). Metode penelitian bidang sosial.

Sudaryono, D. (2017). Metodologi Penelitian: Penelitian Kualitatif. Depok: PT. RajaGrafindo Persada, Depok.

Sugiyono, D. R. (2009). Metodologi penelitian pendidikan. Bandung Alf.

Utsmaini, muhammad bin shalih. (2009). qawaid fi al imla.Pdf (p. 16).

Zulhannan. (2015). Teknik Pembelajaran Bahasa Arab Interaktif. Jakarta. 